\title{
Tingkat Pengetahuan, Perilaku, dan Kepatuhan Berobat Orangtua dari Pasien Epilepsi Anak di Medan
}

\author{
Johannes H. Saing \\ Departemen Ilmu Kesehatan Anak, Fakultas Kedokteran Universitas Sumatera Utara / RSUP H. Adam \\ Malik Medan
}

Latar belakang. Beberapa kepustakaan menyatakan, masih kurang pengetahuan orangtua tentang penyakit epilepsi. Perilaku negatif terhadap anak pasien epilepsi disebabkan karena ketidaktahuan dan kesalahan pengertian terhadap penyakit epilepsi.

Tujuan. Mengetahui tingkat pengetahuan, perilaku, dan kepatuhan berobat pada orangtua dari anak pasien epilepsi.

Metode. Penelitian merupakan suatu studi deskriptif terhadap 65 orangtua dan pengasuh dari anak pasien epilepsi (usia 0-18 tahun) yang datang ke poliklinik neurologi anak RSUP H. Adam Malik Medan, antara bulan Januari-Maret 2008. Digunakan kuesioner yang terdiri dari 39 pertanyaan yang diisi sendiri oleh orangtua ataupun pengasuh.

Hasil. Dari 65 orang responden, 89,2\% adalah orangtua dari anak pasien epilepsi. Responden (46,2\%) berusia 31-40 tahun, dan 13,8\% berpendidikan setingkat universitas. Dari hasil kuesioner yang menilai tingkat pengetahuan didapat $82,5 \%$ pernah mendengar tentang epilepsi, tetapi $92,1 \%$ di antaranya menjawab masih memerlukan informasi lebih tentang epilepsi. Pada 55,6\% responden setuju bahwa epilepsi dapat menyebabkan perubahan perilaku. Mengenai kepatuhan berobat, 79,4\% responden secara teratur mendapat obat anti epilepsi.

Kesimpulan. Meskipun tingkat kepatuhan berobat cukup baik, tetapi sebagian besar orangtua dan pengasuh dari anak epilepsi pernah mendengar tentang epilepsi tetapi informasi yang didapat masih terbatas. Mereka membutuhkan tambahan informasi tentang penyakit epilepsi dan pengobatannya. Perlu dilakukan program edukasi dan penyebaran informasi pada orangtua dari anak pasien epilepsi dan masyarakat di Medan dan sekitarnya.(Sari Pediatri 2010;12(2):103-7).

Kata kunci: tingkat pengetahuan, perilaku, kepatuhan, epilepsi

\footnotetext{
Alamat korespondensi:

Dr. Johannes H. Saing, SpA. Departemen Ilmu Kesehatan Anak FK USU/ RSUP H. Adam Malik, Medan. Jln. Perwakilan No.14 Purwosari, Komp. DPRD Sumut, Medan 20239. Email: jhsaing.saing@gmail.com HP 08126033784
}

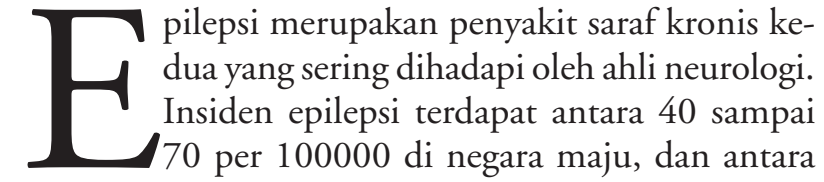
100 hingga 190 per 100000 penduduk di negara 
berkembang. ${ }^{1}$ Insiden epilepsi di RS Dr. Cipto Mangunkusumo Jakarta pada tahun 1991, 3 per 1000 kasus. $^{2}$

Peran keluarga sangat penting dalam proses penyesuaian diri anak maupun keluarga terhadap penyakit kronis. ${ }^{3}$ Meskipun telah banyak kemajuan di bidang kedokteran, akan tetapi masih ada anggapan dan persepsi yang salah tentang epilepsi. ${ }^{4}$ Pemikiran yang salah tentang penyakit ini dapat menimbulkan stigma dan dapat menghambat atau mempengaruhi kepatuhan berobat. ${ }^{5}$ Peningkatan pengetahuan, perbaikan persepsi dan perilaku, dapat menjadi langkah penting untuk meningkatkan perawatan terhadap pasien epilepsi. ${ }^{6}$

Pemahaman pasien dan orangtua/pengasuh tentang manfaat dan pentingnya obat - obat yang diberikan merupakan hal penting dalam kepatuhan berobat. Terdapat beberapa faktor lingkungan yang mempengaruhi hal tersebut, termasuk pengetahuan tentang kesehatan, tingkat pendidikan, dan budaya. Tingkat pendidikan dan budaya dapat mempengaruhi pemahaman tersebut dan diperlukan waktu serta usaha untuk memperbaiki. Kenyataannya, banyak ketidaksesuaian hasil suatu pengobatan karena adanya pengaruh dari faktor budaya, etnis dan sosioekonomi. Hal ini juga akibat perbedaan pemahaman dan persepsi pada saat penerimaan informasi, gaya hidup seharihari dan kepatuhan terhadap pengobatan. Untuk menjembatani kesenjangan informasi ini, dokter anak perlu mengetahui tingkat pengetahuan pasien dan orangtua serta menentukan apakah ada kesalahan informasi atau perbedaan sudut pandang.?
Penelitian bertujuan untuk mengetahui tingkat pengetahuan, perilaku, dan kepatuhan berobat pada orangtua dari anak pasien epilepsi.

\section{Metode}

Penelitian merupakan studi deskriptif yang dilakukan pada 65 orangtua atau pengasuh dari anak pasien epilepsi (usia 0-18 tahun) yang datang ke Poliklinik Neurologi Anak RSUP H. Adam Malik Medan, untuk konsultasi kesehatan anaknya maupun untuk berobat bulan Januari - Maret 2008. Kuesioner diisi oleh orangtua/pengasuh pasien dengan didampingi oleh dokter, yang terdiri dari 39 pertanyaan tentang data demografi, pengetahuan tentang epilepsi dan pengobatannya, perilaku terhadap penyakit ini dan terhadap anak pasien epilepsi, serta kepatuhan berobat. Data diolah dan dianalisis dengan menggunakan SPSS versi 13.

\section{Hasil}

Dilaporkan 65 responden turut dalam penelitian selama periode Januari - Maret 2008, terdiri dari orangtua (58 orang) dan pengasuh (7 orang).

\section{Pengetahuan tentang epilepsi}

Di antara 65 orang responden, didapati 90,5\% pernah mendengar tentang epilepsi. Sebagian besar dari

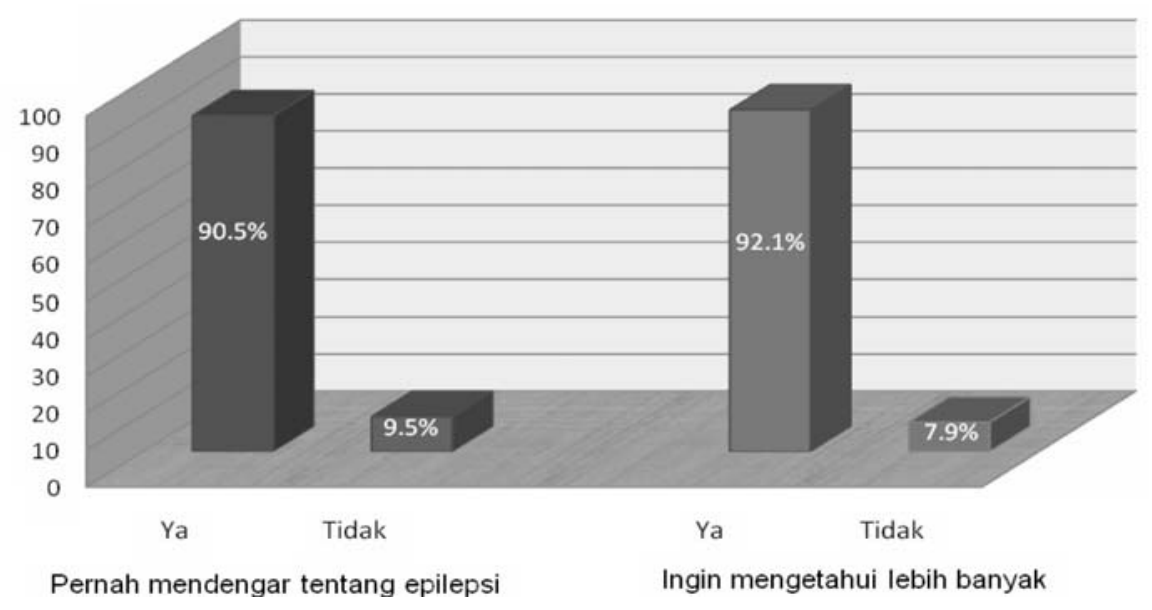

Gambar 1. Persentase responden yang mendapat informasi tentang epilepsi 
responden mendapat informasi dari dokter spesialis anak $(42,1 \%)$, tetangga $(21,5 \%)$, media masa dan iklan $(17,5 \%)$, dan lainnya $(18,9 \%)$.

Ditemukan $26 \%$ orangtua dan pengasuh tidak dapat menjawab penyebab epilepsi, sedangkan $23,8 \%$ menyatakan trauma kepala sebagai penyebab utama epilepsi. Penyebab lain epilepsi antara lain faktor keturunan $(24,3 \%)$, trauma saat hamil atau melahirkan $(3,8 \%)$, dan stres psikologis $(1,6 \%)$. Pada pertanyaan mengenai gejala/ tanda epilepsi, 54\% responden menyebutkan gejala epilepsi adalah kejang dengan kehilangan kesadaran. Dilaporkan 34,9\% responden tidak dapat menjawab pada usia berapa epilepsi dapat terjadi, $27 \%$ menyatakan epilepsi terjadi pada semua usia, $22,2 \%$ menjawab terjadi pada usia 2-14 tahun, dan $14,3 \%$ menjawab terjadi pada usia kurang dari 1 tahun.

Pengetahuan responden tentang epilepsi juga ingin kami ketahui dengan menanyakan dampak penyakit tersebut terhadap anak.

Tabel 1. Data demografi responden

\begin{tabular}{lc}
\hline Variabel & $\mathrm{n}(\%)$ \\
\hline Responden & \\
Orangtua & $58(89,2)$ \\
Pengasuh & $7(10,8)$ \\
Usia (tahun), & \\
$<30$ & $15(23,1)$ \\
$31-40$ & $30(46,2)$ \\
$>40$ & $20(30,7)$ \\
Tingkat pendidikan & \\
Universitas & $9(13,8)$ \\
SMU tamat & $31(47,7)$ \\
SMU, tidak tamat & $8(12,3)$ \\
Lainnya & $17(26,2)$ \\
\hline
\end{tabular}

Setelah serangan kejang, hanya $12,7 \%$ responden membawa anak ke ahli neurologi sebagai pertolongan pertama dan 41,3\% membawa anak ke dokter umum. Dari semua responden, $38,1 \%$ mengetahui tentang pengobatan epilepsi, 40,6\% pernah mendengar tentang obat anti epilepsi, tetapi $25,5 \%$ responden telah mengetahui efek samping dari obat anti epilepsi.

Rerata skor tingkat pengetahuan responden adalah $6,73( \pm 2,31$ ), dengan cut off point 14 (skor maksimal $=28)$.

\section{Pola perilaku terhadap epilepsi dan anak pasien epilepsi}

Sebagian besar responden (81\%) mau memberitahu penyakit epilepsi yang diderita anaknya kepada keluarga ataupun tetangga. Alasan responden yang tidak memberitahu penyakit epilepsi anaknya, antara lain karena menganggap keadaan tersebut merupakan rahasia keluarga, karena merasa masyarakat akan bersikap buruk terhadap pasien epilepsi, dan karena penyakit epilepsi dan penyebabnya itu masih salah dimengerti kebanyakan orang. Ditemukan 67\% responden menyatakan bahwa anak epilepsi berbeda dari teman sebaya atau saudaranya yang lain.

\section{Kepatuhan berobat}

Dari seluruh responden, $79.4 \%$ menyatakan rutin/ selalu membawa anaknya berobat ke dokter. Responden yang kurang patuh atau tidak rutin berobat, 25\% tidak yakin bahwa anaknya akan sembuh, 20\% menyebutkan karena alasan kesulitan keuangan, 8\% karena sulit mendapatkan obat yang diresepkan, dan selebihnya tidak tahu atau tidak dapat menjawab.

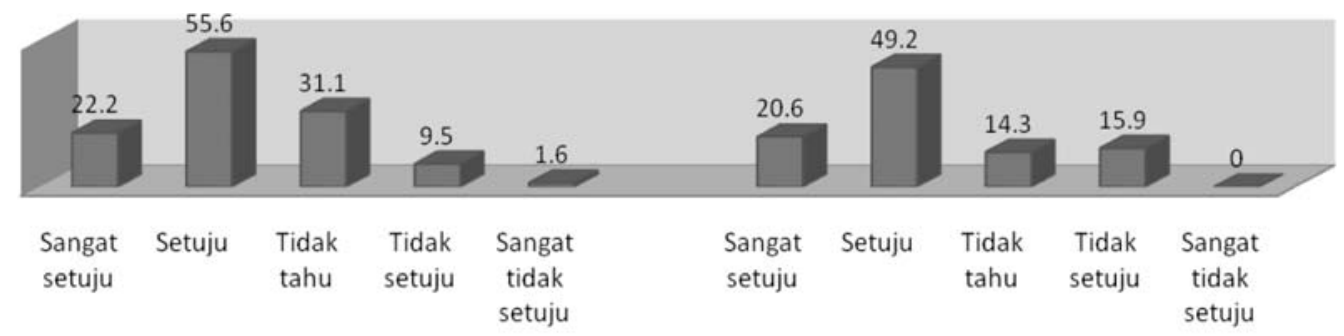

Epilepsi menyebabkan perubahan perilaku

Epilepsi berhubungan dengan kesulitan belajar

Gambar 2. Pengetahuan responden akan dampak epilepsi 

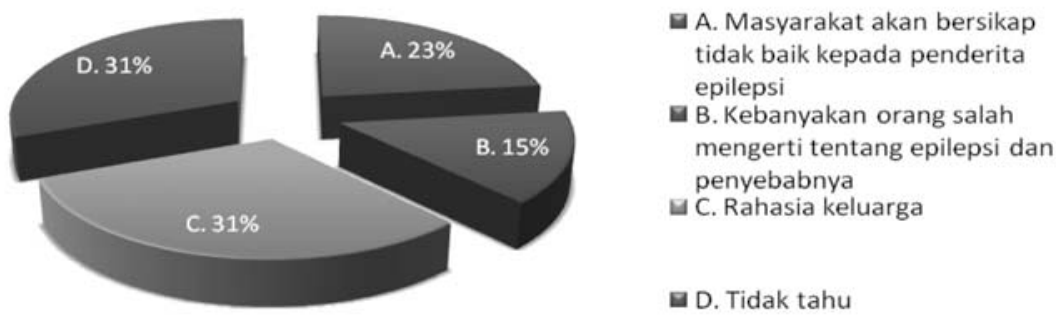

口. Tidak tahu

Gambar 3. Alasan responden tidak memberitahukan penyakit anaknya

\section{Pembahasan}

Beberapa penelitian sebelumnya menemukan bahwa tingkat pengetahuan masyarakat tentang epilepsi masih terbatas dan sikap serta perilaku terhadap penyakit ini bervariasi dan dipengaruhi oleh kebudayaan..$^{8-10}$ Pada penelitian kami, ditemukan bahwa skor tingkat pengetahuan rendah yaitu dengan rerata $6,73( \pm 2,31)$. Sementara itu suatu penelitian di Amerika, melaporkan rerata skor pengetahuan $15,3 .{ }^{11}$ Suatu survei terhadap penduduk Amerika Serikat pada tahun 2002 juga menyimpulkan bahwa secara keseluruhan pengetahuan masyarakat tentang epilepsi masih sedikit. Juga dilaporkan, meskipun prevalensi epilepsi rendah di AS, sebagian besar masyarakat pernah melihat serangan kejang epilepsi, baik melihat langsung ataupun melalui televisi. Sekitar sepertiga masyarakat mengenal gejala epilepsi, tetapi hanya sedikit yang paham tentang penyakit epilepsi, cara mengatasi kejang, ataupun mengetahui dasar terjadinya epilepsi. ${ }^{8}$ Suatu survei di Inggris tahun 2001 juga menunjukkan terdapat kesenjangan perilaku dan pengetahuan tentang epilepsi dapat berpotensi menimbulkan perilaku yang berbedabeda. ${ }^{12}$

Pada penelitian kami, responden yang tidak memberitahu saudara ataupun teman tentang penyakit epilepsi anaknya beralasan karena sikap buruk masyarakat terhadap pasien epilepsi, karena penyakit dan penyebabnya itu masih salah dimengerti oleh sebagian besar orang disekitarnya, dan merupakan rahasia keluarga. Perilaku masyarakat terhadap pasien epilepsi dan sikap buruk lainnya merupakan hal yang dapat menghalangi keberhasilan pengobatan epilepsi, sehingga penyebaran informasi dan pengembangan program pendidikan masyarakat merupakan hal yang masuk akal dan penting. ${ }^{13}$ Pemikiran yang buruk tentang epilepsi merupakan salah satu hal penting yang menyebabkan perilaku negatif pada pasien epilepsi dan keluarganya. Fernandez $\mathrm{dkk}^{14}$ dalam studinya menyatakan bahwa pemikiran tersebut tidak hanya terjadi karena kurangnya informasi tetapi juga oleh karena perilaku yang salah terhadap epilepsi.

Hampir seperlima dari 50 juta kasus epilepsi berada di negara berkembang. Sekitar 90\% dari kasus epilepsi di negara berkembang tidak mendapat pengobatan yang sesuai. ${ }^{1516,17}$ Di negara berkembang, kesulitan utama dalam proses pengobatan yang efektif adalah penyediaan obat yang tidak mencukupi, kurangnya edukasi pada pasien dan keluarga serta ketidakpatuhan berobat pada sebagian pasien. ${ }^{6} 18$ Akibatnya pasien epilepsi makin terpuruk dan memiliki kualitas hidup yang lebih rendah dibanding pasien penyakit kronis lainnya. ${ }^{15}$ Pada penelitian kami masih dijumpai responden yang tidak rutin/tidak selalu membawa anaknya berobat dengan alasan kesulitan biaya, tidak yakin akan kesembuhan anaknya dan sebagainya. Beberapa jenis obat anti epilepsi yang merupakan first drugs sesuai dengan sindrom epilepsi tidak ditanggung atau disubsidi oleh pemerintah, sehingga masyarakat dengan kemampuan ekonomi terbatas tidak dapat membeli obat tersebut.

Usaha untuk menjembatani adanya kesenjangan pengobatan dan usaha untuk menurunkan beban pasien epilepsi tidaklah mudah dan memiliki banyak tantangan. Faktor kebudayaan, kurangnya skala prioritas, infrastruktur kesehatan yang tidak baik dan kurangnya penyediaan obat anti epilepsi, mahalnya obat anti epilepsi, dapat menghalangi proses tatalaksana epilepsi yang ideal. ${ }^{13,19,20}$ Dukungan sosial dan penyediaan informasi yang tepat dan sesuai tentang 
epilepsi dan pengobatannya, adanya sikap positif keluarga dan jaminan perawatan kesehatan efektif bagi anak epilepsi sangat diperlukan.

\section{Kesimpulan}

Kepatuhan berobat pada orangtua dan pengasuh dari anak pasien epilepsi pada umumnya baik, meskipun tingkat pengetahuan terhadap penyakit epilepsi masih rendah. Masih terjadi kesenjangan informasi dan dibutuhkan tambahan informasi tentang epilepsi dan tata laksananya. Program edukasi, penyebaran informasi kepada orangtua dari pasien epilepsi anak dan masyarakat di Medan dan sekitarnya akan sangat membantu mengatasi masalah tersebut.

\section{Daftar pustaka}

1. Sridharan R. Epidemiology of epilepsy. Current Science 2002; 82:664-70.

2. Passat J. Kelainan paroksismal. Dalam: Soetomenggolo TS, Ismael S, penyunting. Neurologi Anak. Edisi kedua. Jakarta: Ikatan Dokter Anak Indonesia; 1999.h.190-7.

3. Thornton N, Hamiwka L, Sherman E, Tse E, Blackman M, Wirrell E. Family function in cognitively normal children with epilepsy: Impact on competence and problem behaviors. Epilepsy \& Behavior 2008;12:90-5.

4. Kwong KL, Wong SN, So KT. Parental perception, worries and needs in children with epilepsy. Acta Paediatr 2000; 89:593-6.

5. Trana D, Odermatta P, Singphuoangpheta S, DruetCabanacc M, Preuxc P. Epilepsy in Laos: Knowledge, attitudes, and practices in the community. Epilepsy \& Behavior 2007; 10:565-70.

6. Sureka RK, Sureka R. Knowledge, attitude and practices with regard to epilepsy in rural north-west India. Ann Indian Acad Neurol 2007;10:160-4.

7. Winnick S, Lucas DO, Hartman AL, Toll D. How Do You Improve Compliance? Pediatr 2005;115:e718-24.

8. Kobau R, Price P. Knowlwdge of epilepsy and familiarity with this disorder in the U.S. population: results from the 2002 health styles survey. Epilepsia 2003; 44:1449-54.

9. Mirnics Z, Czikora G, Zavecs T, Halasz P. Changes in public attitudes toward epilepsy in Hungary: results of surveys conducted in 1994 and 2000. Epilepsia 2001; 42:86-93.

10. Fong G, Hung A. Public awareness, attitude, and understanding of epilepsy in Hongkong. Epilepsia 2002; 43:311-6.

11. Aramyan L. Survey of parents of children with epilepsy in Yerevan, Armenia. Knowledge, attitude, compliance with treatment (dissertation). Yerevan: American University of Armenia, 2005.

12. Jacoby A, Gorry J, Gamble C, Baker GA. Public knowledge, private grief: a study of public attitudes to epilepsy in the UK and implications for stigma (thesis). Liverpool: University of Liverpool, 2001.

13. Boer HM. Epilepsy and society. Epilepsia 1995; 36Supl $1: S 8-11$.

14. Fernandez PT, Salgado PCB, Noronha ALA, Barbosa FD, de Souza EAP, Li LM. Stigma scale of epilepsy: conceptual issues. J Epilepsy Clin Neurophysiol 2004; 10:213-8

15. Scott RA,Lhatoo SD, Sander JWAS. The treatment of epilepsy in developing countries: where do we go from here? Bulletin of the World Health Organization 2001; 79:344-51.

16. Khatria A, Iannacconea ST, Ilsyab MS, Abdullahb M, Saleem S. Epidemiology of epilepsy in Pakistan: review of literature. JPMA 2003;53:594-7.

17. Valvi C, Daga S, Kabade U, Agarwal M. Childhood epilepsy: management in resource-limited setting. Ann Indian Acad Neurol 2008;1 1:33-6.

18. Odermatt P, Ly S, Simmala C, Angerth T, Phongsamouth V, Mac TL, dkk. Availability and costs of antiepileptic drugs and quality of phenobarbital in Vientiane Municipality, Lao PDR. Neuroepidemiol 2007;28:169-74.

19. Kale R. Bringing epilepsy out of the shadows, wide treatment gap needs to be reduced. BMJ 1997;315:2-3.

20. Fernandez PT, de Souza EAP. Identification of family variables in parents' groups of children with epilepsy. Arq Neuropsiquiatr 2001;59:854-8. 